\title{
On the Communicative Value of Multi-Grade Denotation
}

\author{
Xiaoying Zhou ${ }^{1}$ \\ ${ }^{1}$ School of Foreign Languages, Nanchang Normal University, Nanchang, China \\ Correspondence: Xiaoying Zhou, School of Foreign Languages, Nanchang Normal University, Nanchang, China.
}

Received: April 2, 2018 Accepted: April 24, 2018 Online Published: May 10, 2018

doi:10.11114/ijecs.v1i1.3265

URL: https://doi.org/10.11114/ijecs.v1i1.3265

\begin{abstract}
In this paper the author will discuss the communicative value of Multi-Grade Denotation. Denotation has always been one of the main topics in both linguistics and philosophy. And it is also very widely used in human's daily communication. In our daily conversation, denotation is a means used at any moment. G-1 Denotation is suitable only for low situation communication. It has no special situational value. If we leap from G-1 Denotation to G-2 Denotation, this is the new information it conveys, possessing a certain communicative value. The G-3 Denotation (the denotation in plays and TV screens) is a rather special type of denotation. Multi-Grade denotation is a special communication means, but it possesses special communication value.
\end{abstract}

Keywords: the communicative value, semantic feature, philosophy, psychology, multi-grade Denotation

\section{Introduction}

By denotation is meant the address of a specific thing in the object world, which has long been a problem of common concern by philosophers and logicians since Plato and Aristotle in ancient Greece. And it is also one of the major topics for research in modern linguistics. Denotation is a linguistic phenomenon of denoting a specific thing with a proper noun. For example, Charles Chaplin refers to American famous farce and film actor and was concurrently a play writer in nineteenth century; Darwin refers to the great British scientist in the nineteenth century, the founder of the Theory of Evolution, etc. The word which is used to address a certain thing is called copy word. If the copy word is $\mathrm{C}$ and the addressee is $\mathrm{X}$, then the above denotation can be generalized as $\mathrm{C}(\mathrm{X})$. For example, Aristotle refers to the Father of Philosopher in ancient Greece and also refers to the student of Plato. Therefore, the formula $\mathrm{C}(\mathrm{X})$ here equals to $\mathrm{C}(\mathrm{X} 1$, $X 2)$, i.e. $C(X)=C(X 1, X 2)$. Similarly, with the exception of denoting the man himself, the name Donald J. Trump refers to US president currently in office. For example, Lu Xun refers to the following:

(1) Zhou Shuren (X1);

(2) Modern great writer in China (X2);

(3) Modern great thinker in China (X3);

(4) Proletarian fighter (X4);

(5) Patriot (X5).

Therefore, $\mathrm{C}(\mathrm{X})=(\mathrm{X} 1, \mathrm{X} 2, \mathrm{X} 3, \mathrm{X} 4, \mathrm{X} 5)$. Here, the copy word $\mathrm{C}$ possesses multi-denotative meanings. In other words, all the above five denotations $(\mathrm{X} 1, \mathrm{X} 2, \mathrm{X} 3, \mathrm{X} 4, \mathrm{X} 5)$ can be put under the sentence "Lu Xun is ..." to form a logical sentence. This is called Grade-1 Denotation, i.e. the copy word C is exactly equal to (X1, X2, X3, X4, X5) --- the commonly used sentences in daily conversations. However, in certain special situations the formula $\mathrm{C}(\mathrm{X})$ does not hold water. It belongs to Grade-2 or Grade-3 Denotations.

\section{The Communicative Value of Multi-Grade Denotation}

In our daily conversation, denotation is a means used at any moment. Generally speaking G-1 Denotation is rather widely used in communication, but it has rather low communicative value. Therefore, we can call it as belonging to "low situational communication". G-2 Denotation refers to the sentences which cannot be expressed with $\mathrm{C} \leq \mathrm{X} 1, \ldots \ldots . \mathrm{Xn}$, but they are a communicative means in special situations, a rather popular phenomenon of denotation in film and play situations. G-3 is a special form of G-2 Denotation. That is, the copy word C still retains its original meaning when the specific film and play situations have changed. As it is mentioned above, in different situations, people use different grade denotations. Generally speaking, the maximum denotation is G-3 Denotation. Let's explain them one by one: 


\section{(1) G-1 Denotation}

G-1 Denotation is a rather popular denotation phenomenon in daily conversation. It is rather widely used in communication, but it has rather low communicative value. Therefore, we can call it as belonging to "low situational communication". Its basic formula is $\mathrm{C} \neq \mathrm{X}$ or $\mathrm{C}(\mathrm{X})$. All the following are the examples of G-1 Denotations:

(A) Donald J. Trump is the US president currently in office.

(B) Einstein is the founder of the Theory of Relativity.

(C) Birds are the animals with wings.

(D) Beijing is the capital city of China.

(E) The Nansha Islands are territory of China.

Generally speaking, $\mathrm{C}(\mathrm{X})$ denotation sentences possess the following semantic features:

1 The addressee $\mathrm{X}$ can be equal or greater than its copy word $\mathrm{C}$. In other words, the connotation of $\mathrm{C}$ is equal to or greater than its addressee $X$. For example, among the above sentences:

(A) Donald J. Trump $=$ the US president currently in office.

(B) Einstein $=$ the founder of the Theory of Relativity.

(C) Parrots $<$ birds with wings.

(D) Beijing $=$ the capital city of China.

(E) The Nansha Islands $<$ the territory of China.

2 In the G-1 Denotation sentences, all the X's appear as its denotative meanings. And their original meanings do not appear in the conversation. For example:

The sentence "Lu Xun is an old man with short hair and a moustache" would be meaningless. However, the sentence "Lu Xun is a modern Chinese great writer" $(\mathrm{C}(\mathrm{X}))$ would possess communicative meaning. Similarly, the sentence "The Nansha Islands are a group of islands" would have no communicative meaning as well. This shows that the denotation objects $\mathrm{X} 1 \ldots \mathrm{Xn}$ have communicative meanings. Therefore, the above $\mathrm{C}(\mathrm{X} 1 \rightarrow \mathrm{X} 2)$ may be expressed with the following equation:

$$
\mathrm{C} \leq \mathrm{X} 1 \ldots \mathrm{Xn}
$$

However, in some special situations, the above formula $\mathrm{C} \leq \mathrm{X} 1 \ldots \mathrm{Xn}$ does not hold water in the case multi-Grade denotations is involved.

\section{(2) G-2 Denotation}

G-2 Denotation refers to the sentences which cannot be expressed with $\mathrm{C} \leq \mathrm{X} 1 \ldots \mathrm{Xn}$, as its copy word $\mathrm{C}$ is not equal to the denominated things $\mathrm{X} 1 \ldots \mathrm{Xn}$ due to the sake of time or space factors. But, they are a communicative means in special situations. Here $\mathrm{C}$ replaces $\mathrm{X}(\mathrm{X} 1 \ldots \mathrm{Xn})$. It can be expressed in semantic formula as follows:

$$
\mathrm{C} \rightarrow \mathrm{X}(\mathrm{X} 1 \ldots \mathrm{Xn}) \text {. }
$$

From the formula we can see that the copy word $C$ is not $X$, but "replace" $\mathrm{X}(\mathrm{X} 1 \ldots \mathrm{Xn})$ under certain situations. For example, there are such cases on the stage or on the TV screens. It is well-known that Gu Yue is a China's special actor, who plays "Mao Tsetung" on the stage or on TV screen. The role "Mao Tsetung" he acts is so vivid that it has moved millions of people's hearts. However, under special situations of stage or TV screen, whether the film (or play actors) or the audience call him "Mao Tsetung" not Gu Yue. Therefore, if it is expressed with rather detailed semantic formula it would be like this:

$$
\mathrm{C} 2 \rightarrow \mathrm{X}[\mathrm{C} 1(\mathrm{X} 1 \ldots \mathrm{X} 5)]
$$

If we take "Gu Yue playing the part of Mao Tsetung" to replace the above formula, then the formula would become the following expression:

$$
\begin{array}{cccc}
\mathrm{Gu} \text { Yue } & \rightarrow \text { Mao Tsetung [ great thinker, ... great ... ] } \\
\mathrm{C} 2 & \mathrm{C} 1 & \mathrm{X} 1 & \mathrm{Xn}
\end{array}
$$

When we separate ourselves from the specific situations, the $\mathrm{X}$ represented by $\mathrm{C}$ would hold no water. For example, at Gu Yue's home, in the theater... he can only be addressed as Gu Yue, not "Mao Tsetung". Terence Hawkes said in his "Structuralism and Semiotics": "So far as their features are concerned the audile and time symbols tend to be symbolism, while the visual and space symbols tend to be images" (Terence Hawkes (1977), "Structuralism and Semiotics” P139 University California Press. Berkeley, California. USA). Yu Jianzhang and Ye Shuwu said in their 
"symbols: Language and Art": "The denotative meaning is an action projected on some object thing" (Yu Jianzhang \& Ye Shuwu (1988) "symbols: Language and Art” P213 Shanghai People's publishing House, Shanghai, China). All these explain the "quadratic denotation" function of copy word C. In semantic formula, it can be expressed as follows:

\begin{tabular}{|c|c|c|}
\hline $\mathrm{C}$ & {$[\mathrm{C} 1$} & $(\mathrm{X} 1 \ldots \mathrm{Xn})]$ \\
\hline $\begin{array}{l}\text { Gu Yue } \\
<\text { name }>\end{array}$ & Mao Tsetung & $\begin{array}{l}\text { Mao Tsetung } \\
\langle\text { nerson }>\end{array}$ \\
\hline
\end{tabular}

Similarly the national grade actor Bao Guoan who plays Cao Cao in TV play "Three Kingdoms" belongs to this case. In these situations, although both $\mathrm{Gu}$ Yue and Bao Guoan are not Mao Tsetung and Cao Cao respectively, they are still addressed as "Mao Tsetung" and "Cao Cao" in the play script or in the mouth of the audience respectively. This is called G-2 Denotation, a rather popular phenomenon of denotation in specific film and play situations.

\section{(3) G-3 Denotation}

This is a special form of G-2 Denotation. That is, the copy word C still retains its original meaning when the specific film and play situations have changed. It is especially so when $\mathrm{C} 3<\mathrm{C} 2<\mathrm{C} 1$. $\mathrm{C} 3<\mathrm{C} 2<\mathrm{C} 1$ refers to the fact that in the minds of the audience the PE of $\mathrm{C} 1$ is greater than $\mathrm{C} 2(\mathrm{C} 1 \mathrm{E}>\mathrm{C})$ and $\mathrm{PE}$ of $\mathrm{C} 2$ is greater than $\mathrm{C} 3(\mathrm{C} 2 \mathrm{E}>\mathrm{C} 3)$. For example, once when a certain actor who used to act the role of "Liu Shaoqi" acted other role, sometimes the audience may say: "Look, Liu Shaoqi!", especially in the mouth of the children, because people seldom know his name. Therefore they "have to" call him like this. Similarly, when Gu Yue appeared in the spring Festival Theatrical Party, people may say: "Look, Mao Tsetung!” etc. The semantic formula of this G-3 Denotation is as follows:

\section{C3 $\mathrm{X} \quad\{\mathrm{C} 2 \mathrm{X}[\mathrm{C} 1(\mathrm{X})]\}$}

It can be seen from the formula that $\mathrm{C} 3$ denotes $\mathrm{C} 1$ directly with $\mathrm{C} 2$ crossed over, resulting in a G-3 Denotation. If the above formula is written in vertical formula, then it is like this:

$$
\begin{gathered}
\mathrm{C} 3(\mathrm{X} 1 \ldots \ldots \mathrm{Xn}) \ldots \ldots \ldots \ldots \ldots \ldots \ldots . . . \mathrm{G}-3 \\
\downarrow \quad \mathrm{C} 2(\mathrm{X} 1 \ldots \ldots \mathrm{Xn}) \ldots \ldots \ldots \ldots \ldots \ldots \ldots \mathrm{G}-2 \\
\rightarrow \quad \mathrm{C} 1(\mathrm{X} 1 \ldots \ldots . \mathrm{Xn}) \ldots \ldots \ldots \ldots \ldots . \mathrm{G}-1
\end{gathered}
$$

It can be seen from the above formula that copy word $\mathrm{C}$ has experienced the "third leap" of denote X. Among these denotation $\mathrm{C} 1$ equals to $(\mathrm{X} 1 \ldots \mathrm{Xn}), \mathrm{C} 2$ (X1..Xn) denotes $\mathrm{C} 1$ and $\mathrm{C} 3(\mathrm{X} 1 \ldots \mathrm{Xn})$ denotes $\mathrm{C} 2$. Therefore $\mathrm{C} 3$ can denote $\mathrm{C} 1(\mathrm{X} 1 \ldots \mathrm{Xn})$ directly. This type of G-3 denotation possesses semantic features in special language situations.

In people's daily conversation the so called G-3 Denotation phenomenon occurs frequently. This type of G-3 Denotation possesses the following semantic features:

(i). This type of G-3 Denotation appears mostly in stage and screens. When the influence of the copy word C1 is greater than the influence of copy word C2 of G-2 Denotation or the denote by the G-2 Denotation C2 is seldom known by the audience, people often like to denote C3 with C1. For example, when the name of the actor of Liu Shaoqi in a certain TV play is not very familiar to the audience and when he appears in another TV play, the audience may sometimes call him "Liu Shaoqi" as he plays another role in this TV play, for example a policeman. If we use symbol Y to represent this policeman, then this semantic formula would be like this:

$$
\begin{aligned}
& \mathrm{C} 3(\mathrm{X} 1 \ldots . . \mathrm{Xn}) \ldots \ldots \ldots \ldots \ldots \ldots \ldots . . . . . . . . . . .3
\end{aligned}
$$

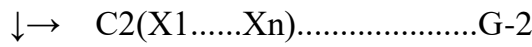

$$
\begin{aligned}
& \rightarrow \quad \mathrm{C} 1(\mathrm{X} 1 \ldots . . \mathrm{Xn}) \ldots \ldots \ldots \ldots \ldots \ldots . . . . \mathrm{G}-1
\end{aligned}
$$

It can be seen from the formula that both $\mathrm{X}$ and $\mathrm{Y}$ are two denotes represented by $\mathrm{C}$, resulting in

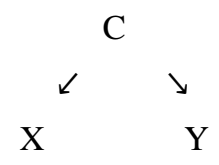

However in the triangular relations the popular effect $(\mathrm{PE})$ of copy word $\mathrm{C}$ is far less than $\mathrm{X}$, therefore

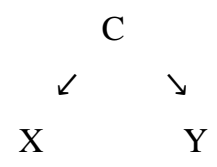

In this case, people may habitually call $\mathrm{Y}$ as $\mathrm{X}$. For example Mr. Bao Guoan once played the role Cao Cao in the historical play "The Three Kingdoms", but he played the role of Emperor tan in historical play "Wu Zetian". As Cao 
Cao is a man rather popular in China and Bao Guoan may not be so popular in China to some extent, therefore people may call him Cao Cao, regardless of what play he appears. In fact in practical life there are many successful actors with their true names rather unpopular among the audience, but on the contrary the role he plays becomes his (or her) name, resulting in an illogical semantic formula. This type of example is too many to list:

$$
\mathrm{X}=\mathrm{Y}
$$

Here the copy word $\mathrm{C}$ is in a position of being "not indispensable"

(ii). Another features of the semantic formula $\mathrm{X}=\mathrm{Y}$ is that as the common $\mathrm{C}(\mathrm{X}, \mathrm{Y})$ of $\mathrm{X}$ and $\mathrm{Y}$ becomes $\mathrm{C}>(\mathrm{X}, \mathrm{Y})$ structure, therefore in the minds of ordinary audience $\mathrm{X}$ tends to replace $\mathrm{Y}$. In this case the confusion state of $\mathrm{X}$ with $\mathrm{Y}$ may appear. For example, in the historical plays "The Three Kingdoms" and "Wu Zetian", the roles Cao Cao and the Emperor Tan were played by the same person --- Bao Guoan, but to those who are not familiar with these two historical plays (for example foreign audience) they may regard both the roles as Cao Cao. This is the negative effect the semantic formula $\mathrm{X}=\mathrm{Y}$ may cause.

(iii).In G-3 Denotation if copy word C possesses rather greater PE than its denote, then

$$
\mathrm{C}>\mathrm{X}(\mathrm{x} 1 \ldots \mathrm{xn})
$$

When this $\mathrm{C}$ denotes another $\mathrm{Y}$ in different stage (or play) situation people may still use $\mathrm{C}$ to dente $\mathrm{X}$ and $\mathrm{Y}$, resulting in

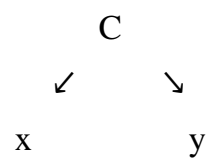

It can be seen from here that the copy word $\mathrm{C}$ is far greater than its denotes $\mathrm{X}$ and $\mathrm{Y}$, making them in an inferior position. For example, China's big singing star Mao A'ming is a very popular singer among the audience. However she appeared in TV plays for many times, performing a certain role. At this time in the minds of the audience the woman before their eyes is not the role she plays but Mao A'ming herself, whether the role is X or Y. Thus

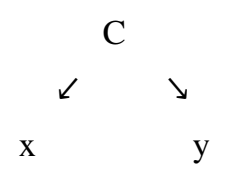

Becomes the semantic formula

$$
\mathrm{x}----\mathrm{C}----\mathrm{y}
$$

The reader can see for sure that what a distinguished position the copy word $\mathrm{C}$ is in. At this time what the audience concern is not the story of the play in which X or Y appears but Mao A'ming herself. This is the semantic effect produced by the semantic formula

$$
\mathrm{C}>\mathrm{X}(\mathrm{x} 1 \ldots \mathrm{xn}) / \mathrm{Y}(\mathrm{y} 1 \ldots \mathrm{yn})
$$

Similarly if the special actor Gu Yue plays another role in another play (for example a service man), its PE is quite obvious. The same is true of Sun Feihu --- the actor of Jian Kaishek. He is also not suitable to perform another positive role with rather "low" social position. This case can be expressed with the following semantic formula

$$
\mathrm{C}>\mathrm{X}
$$

Here two points may be pointed out:

(I) When the PE of the copy word $\mathrm{C}$ is far greater than its denote $\mathrm{X}$ or $\mathrm{Y}$;

(II) The denote $\mathrm{X}$ or $\mathrm{Y}$ denoted by the copy word $\mathrm{C}$ is not very important in the story of the play. In the above two cases swing to the function of the PE, the expression of the story of the play may be influenced. If the copy word $\mathrm{C}$ denotes an ordinary character in an ordinary play story, its PE may concentrate on this famous film star, ignoring the development of the play story. Therefore the result is just the reverse. For example, Mao A'ming's acting the role of an ordinary service girl in a common TV play belongs to such a case.

Seen from the semantic angle of the denotation, $\mathrm{C}, \mathrm{X}$ and $\mathrm{Y}$ should be roughly match. They should not be allowed to have greater difference. It is only in this case that the performance would be natural and successful. For example, China's famous actress Liu Shaoqin has acted the role of Queen (for example in the play "Fire Burning Yuan Min Park") and empress dowager (for example in the film "Ci Xi Dowager"), is just a very exact example of $\mathrm{C}$ which is roughly in match with X/Y. Its semantic formula is

$$
\mathrm{C} \approx \mathrm{X} / \mathrm{Y}
$$


On the contrary, when she first appeared on the screen she could only act the role of a little girl in the film "Xiao Hua". This is both an arbitrary arrangement of the director and is also an objective law.

(iv) On the contrary if the copy word $\mathrm{C}$ is far inferior to its denote $\mathrm{X} / \mathrm{Y}$, resulting in the semantic formula $\mathrm{C}<\mathrm{X} / \mathrm{Y}$

At this time as the denote $\mathrm{X}$ or $\mathrm{Y}$ of the copy word $\mathrm{C}$ far surpasses the $\mathrm{PE}$ of $\mathrm{C}$ itself in the eyes of the audience, they should try their best to make their role meet the requirement of $\mathrm{X}$ or $\mathrm{Y}$. In other words, $\mathrm{C}$ should endeavor to make $\mathrm{C}<$ $\mathrm{X} / \mathrm{Y}$ become $\mathrm{C}=\mathrm{X} / \mathrm{Y}$. However this process is a very hard but very meaningful one. It's true that in practical situation, when $\mathrm{C}<\mathrm{X} / \mathrm{Y}$ it is not an easy task to make $<$ become $=$ in the above formula. But through the hard work of $\mathrm{C}$ it is possible for him to make $<$ become $\approx$. Many film stars have experienced such a process before their success. For example, the famous film star Liu Xiaoqin had acted some rather unimportant roles before her success. It is only when she played the role of the Dowager in "Fire Burning Yuan Minyuan" and the Dowager Wu Zetian in the historical play "Wu Zetian" that she became a suitable role in the eyes of the audience. That is to say $\mathrm{C} \approx \mathrm{X} / \mathrm{Y}$. This is something many film actors tried to do but it is a target rather difficult to attain.

In order to explain this problem vividly we can design some expressions to show the relations among copy word $\mathrm{C}$ and the denote $\mathrm{X} / \mathrm{Y}$ and their $\mathrm{PE}$, so as to show what are multi-Grade Denotation and their semantic features:

$$
\begin{array}{cc}
\text { (1) } \mathrm{C}=\mathrm{X} / \mathrm{Y} & \mathrm{PE} \rightarrow \mathrm{C} / \mathrm{X} / \mathrm{Y} \text {; } \\
\text { (2) } \mathrm{C}>\mathrm{X} / \mathrm{Y} & \mathrm{PE} \rightarrow \mathrm{C} ; \\
\text { (3) } \mathrm{C}<\mathrm{X} / \mathrm{Y} & \mathrm{PE} \rightarrow \mathrm{X} / \mathrm{Y}
\end{array}
$$

At the beginning of the paper we took Bao Guoan as an example, who used to play the role of Cao Cao in "The Three Kingdoms" and then played the role of the emperor Tan in the historical play "Wu Zetian", no wonder some audience said: "Look, Cao Cao comes out again!" Here, the audience take X (Cao Cao) to denote the copy word C, resulting in a state of putting the cart before the house. It is just because $\mathrm{C}<\mathrm{X}$. On the contrary, if "Mao Testung" acted by our special actor Bao Guoan is compared with "Mao Tsetung" played by other actor, as C $\approx \mathrm{X}$, the audience may say: "Mao Tsetung played by Gu Yue is really excellent! " This is called the function of popular effect PE. Sometimes, the PE can be so great that it can be used to represent his works or role. For example, people sometimes may say "Did you ever read Shakespeare?", meaning "Did you ever read Shakespeare's works?". Here his PE is quite obvious. But we seldom say: "Did you ever read Ba Jin?"

\section{Summary}

This paper discusses the communicative value of Multi-Grade Denotation, their common features and their differences. Denotation is a means used at any moment in our daily conversation. G-1 Denotation is widely used but has low communicative value and belongs to "low situational communication". In other words, G-1 Denotation is only suitable for low situation communication. It has no special situational value. For example, using $\mathrm{Gu}$ Yue to represent Mao Tsetung (the man). It is just as we use "Mao Tsetung" the name to represent Mao Tsetung (the man). There is not any new communicative value, for this is common knowledge with no new information. Communication without new information, its communicative value would be low. However if we use Gu Yue to represent Mao Tsetung (i.e. we leap from G-1 Denotation to G-2 Denotation), although the denote addressed by $\mathrm{C}$ has undergone a "transition", it conveyed an information --- "Gu Yue is quite like Mao Tsetung" or "Mao Tsetung played by Gu Yue is rather excellent!" ... This is the new information it conveyed, possessing a certain communicative value. However if Gu Yue appears in other situation (meaning film situation) and he plays other role (Y), the people may still call him "Mao Tsetung". This "second denotation transition" not only shows the fact that "Mao Tsetung" played by Gu Yue is rather excellent, but also shows that the PE of the other role he played is low. Therefore this G-3 Denotation with "second denotation transition" can convey the following information:

(1) Mao Tsetung is a man familiar to everyone;

(2) Gu Yue is quite like Mao Tsetung;

(3) Mao Tsetung played by Gu Yue is rather excellent;

(4) The PE of another role played by Gu Yue is rather low;

All in all, multi-Grade Denotation is a special communication means, but possesses special communication value. Therefore, it needs a deep-going research. 


\section{References}

Jung, C. (1933). Modern Man in Search of A Soul (Tr. by Huan Qiming). Beijing, China: Workers' Publishing House. 23-54.

Yun, C. (1991). Writing Process and Writing Ability. Guangzhou, China: Modern Foreign Languages. (4), 52-59.

Cassirer, E. (1946). Language and Myth (Tr. by Yu Xiao). Beijing, China: San Lian Shu Dian, 129-201.

Song, R. (1994). The Significance of Proper Noun. Learned Journal of Eastern China Normal University, 5, 69-87.

Shi, Y. (2007). Compositionality of Language Competence: Evidence from Cognitive Psychology. Studies in Language and Linguistics, 3, 59-68.

Sennet, A. (2011). Unarticulated constituents and propositional structure. Mind \& Language, (4), 412-435. https://doi.org/10.1111/j.1468-0017.2011.01423.X

Stanley, J. (2002). Making it articulated. Mind and Language, (1), 149-168. https://doi.org/10.1111/1468-0017.00193

Hawkes, T. (1977). Structuralism and Semiotics. Berkeley, California. USA: University California Press, 138-139. https://doi.org/10.4324/9780203443934

Tu, J. (1988). Selected Works of Famous Linguistics Philosophical Works. Beijing, China: San Lian Shu Dian., $198-200$.

Yu, J., \& Ye S. (1988). Symbols: Language and Art. Shanghai, China: Shanghai People's publishing House., $210-213$.

Barthes, R. (1984). Elements of Semiology. New York, NY, USA: Hill and Wang., 58-61.

$\mathrm{Xu}$, L. (1994). The Width and Depth of Cross-Linguistic studies. Foreign Language Teaching and Research, Beijing, 91-96.

Zhang, Z. (1995). An Account of the Psychological Process of Writing for Chinese Learners of English. Modern Foreign Language. Guangzhou., 152-160.

Zhao, Y. (1995). From Written Discourse to Teaching of Reading. Modern Foreign Languages. Guangzhou, $112-121$.

\section{Copyrights}

Copyright for this article is retained by the author(s), with first publication rights granted to the journal.

This is an open-access article distributed under the terms and conditions of the Creative Commons Attribution license (http://creativecommons.org/licenses/by/4.0/). 